\title{
Entrepreneurial Experience and Usage of External Business Support
}

\author{
Jaroslaw Ropega \\ University of Lodz, Faculty of Management, Poland
}

\section{Abstract}

Previous studies demonstrate that policy makers and practitioners should target support tailored to special needs of novice and habitual entrepreneurs. This paper aims to present a study of the role of prior business experience in the inclination to use external business support and the choice of various forms of this support. Research were conducted on a sample of 373 Polish small innovative enterprises in the fourth quarter of 2017. Enterprises were surveyed by means of a questionnaire using the CATI (Computer Assisted Telephone Interviewing) technique. The findings suggest that habitual entrepreneurs use external business support to a greater extent than novice entrepreneurs but differences between various forms of support used by novice and habitual entrepreneurs are not significant. The presented research results are a starting point for further detailed analyses that should be undertaken to explore the characteristics of habitual entrepreneurs: whether and to what extent entrepreneurs learn from their own experience, what is the impact of success or failure in previous businesses on the current behaviour of entrepreneurs and their companies, and what implications this brings for the development of the future SME support policy.

Keywords: entrepreneurial experience, business support, habitual entrepreneurship JEL classification: L25, L26, L53

\section{Introduction}

\section{The habitual entrepreneurship phenomenon}

Entrepreneurship is the subject of many scientific, economic and political discussions, and enterprises and entrepreneurs are perceived as the key drivers of economic growth (Reynolds et al., 1994; Wennekers and Thurik, 1999; Dominiak, 2005). They contribute to employment growth, improvement of competitiveness and increase in the well-being of societies (Storey, 1994). This approach justifies the widespread policy of supporting entrepreneurship.

Organization for Economic Cooperation and Development (OECD) (1998) indicates that entrepreneurs are the initiators of changes and growth of the market economy, and may accelerate the generation, dissemination and implementation of innovative ideas. Public assistance is mainly focused on novice entrepreneurs who do not have previous business experience. At the same time, there is an increasing knowledge that entrepreneurship is not limited to the creation of a new company as a single action (Sarasvathy et al., 2013; Ucbasaran et al., 2006). An important part of the group of small and medium-sized enterprises are habitual entrepreneurs (Ucbasaran et al., 2008; Westhead et al., 2004; Westhead et al., 2003).

Business exit is an inseparable part of the entrepreneurial process (Detienne, 2010) and may be caused by various causes, such as (see Ropęga, 2013):

- voluntary liquidation in order to take up a better undertaking or employment,

- liquidation for personal reasons, 
- selling the company with a profit to return the invested resources,

- sale or liquidation of the company in order to avoid losses,

- bankruptcy.

Liquidation of economic activity is not limited to reaction on the financial failure of the enterprise. Getting out of business is often entrepreneurial and economic activity for the effective allocation of resources. Many authors show that the phenomenon of multiple business activity is common in many countries, habitual entrepreneurs constitute a large and important segment in the population of entrepreneurs (Westhead et al., 2005, Westhead and Wright, 2015) and can range from 12 to even $64 \%$ of all enterprises (Ucbasaran et al., 2008).

Persons systematically undertaking business activity, one at a time or several activities concurrently, have been the subject of research in many countries with developed economies in the last 20 years (Westhead and Wright, 1998; Taylor, 1999; Ucbasaran et al., 2003, 2008; Pasanen, 2003; Wiklund and Shepherd, 2008; Westhead and Wright, 2017). According to MacMillan (1986), entrepreneurial experience and research concerning habitual entrepreneurs should form the basis for studying the essence of entrepreneurship.

According to Westhead et al. (2004) and Ucbasaran et al. (2006) the universal operationalisation of novice and habitual entrepreneurs are:

Novice entrepreneurs are persons without prior experience (both minority and majority) in the ownership of a business, founders and buyers or heirs of an existing independent enterprise who currently have a minority or majority stake in a newly established, acquired or inherited enterprise.

Habitual entrepreneurs are persons who have or had a minority or majority stake in two or more enterprises, and at least one of them was founded, acquired or inherited. Habitual entrepreneurs include:

- serial entrepreneurs - are persons who have sold or closed at least one business in which they have had a minority or majority stake, and currently hold a minority or majority stake in one independent enterprise that was newly founded, acquired or inherited,

- portfolio entrepreneurs - are persons who currently hold a minority or majority stake in two or more independent enterprises that were newly established, acquired or inherited.

\section{The problem and research questions}

Theoreticians suggest that people with greater human capital resources consisting of attributes achieved are associated with an increased level of productivity (Becker, 1975). Later, the term human capital was extended to the cognitive abilities of entrepreneurs, as well as the cumulative work and habits that can have a positive or negative impact on productivity, both in the market and non-market sectors. Therefore, the human capital of an entrepreneur can shape to some extent his or her business behaviour and activity (Unger et al., 201 1). In the context of entrepreneurship, human capital may have an impact on the identification, search for and exploitation of opportunities, their "quality" in relation to innovation, the survival of the company and its activities (Westhead and Wright, 2017).

Previous experience can be used to improve entrepreneurial skills as well as reputation, which can help reallocate resources in subsequent business ventures that can be founded, acquired or inherited (Shane and Khurana, 2003). Some entrepreneurs may use experience, the ability to deal with formal requirements and gained credibility to obtain funds for further undertakings from banks, venture capital investors or other informal investors. 
Entrepreneurship support policy is widespread in developed countries (OECD, 1998; Reynolds et al., 1994). Objectives of the enterprise policy refer to employment growth, improvement of innovation and competitiveness of enterprises and take the form of "hard" (financial) support and / or "soft" (educational and training).

The issue of the purposefulness and scope of entrepreneurship support is discussed by scientists and politicians. Bridge et al. (2003) are skeptical about the legitimacy of external support for small new companies, citing the verification of market mechanisms. Flynn (1993) warns that support for new companies can cause a "negative selection" and survival of less competitive companies.

According to Cieślik (2014), on the one hand, there is evidence of a failure of mechanisms on the market, requiring correction by the state. On the other hand, there are problems with the proper design and implementation of an effective support policy entrepreneurship addressed to actually needing support and guaranteeing expected effects for the economy.

According to Westhead et al. (2004) and Westhead and Wright (2017) there are significant differences in the profiles and behaviour of entrepreneurs with prior business experience and novice entrepreneurs. If support for entrepreneurship is to be effective it is necessary to focus on the entrepreneur (human capital profiles, motivations, resources, behaviour, performance) rather than the firm (Ucbasaran et al., 2008). The review of the above publications suggests that policy makers and practitioners need to target separate policies towards the varying needs of novice and habitual entrepreneurs.

This study was aimed at examining the behaviour of novice and habitual entrepreneurs in relation to the use of external business support. To achieve the goal, the following research questions were formulated:

1. To what extent habitual and novice entrepreneurs use external business support?

2. What impedes the use of external support by habitual and novice entrepreneurs?

3. What kind of external support are used by habitual and novice entrepreneurs?

In Poland the main barriers to cooperation between enterprises and business environment institutions are: insufficient information and promotion actions, lack of adaptation of the offer to the needs of enterprises, lack of specialized services, complicated regulations (Lisowska, 2014; Markiewicz, 2010; Dominiak, 2016). In Poland, so far, there has been no research on the use of external support by novice and habitual entrepreneurs, hence the author's research fills a gap in this area. The paper also contains indications for further research into the differences of habitual and novice entrepreneurship in the support policy aspects. In-depth research will allow for a better adjustment of the policy to the needs of different groups of entrepreneurs.

\section{Methodology}

Data for the study were collected as part of a comprehensive project entitled "Determinants of the development of entrepreneurship and innovation in small business" ("Uwarunkowania rozwoju przedsiębiorczości i innowacji w małych firmach"), carried out at the Faculty of Management of the University of Lodz, addressed to owners/co-owners of small innovative companies, i.e. companies that in the years 2014-2017 made at least one change related to the introduction of new products/services or upgrading existing ones, or related to the implementation of new technical methods of production/provision of services or their modernisation, or related to the introduction of new or improved methods of company organisation. 
The study was conducted by an experienced research agency. Minimum sample size is 382 , at a confidence level of 0.95 and a margin of error $5 \%$ for 57,2 thousand small companies in Poland. Random sampling was applied. The research sample was selected from the database of enterprises employing from 10 to 49 people containing over 50,000 records, out of which 20,000 enterprises were drawn (from the database, every tenth unit was drawn for examination). The database was purchased from an external company (Bisnode). Enterprises were surveyed by means of a questionnaire using the CATI (Computer Assisted Telephone Interviewing) technique. The total number of completed questionnaires was 400 , the response rate was $35.5 \%$ and the effective response rate was 2.06\%. 373 questionnaires were accepted for the study (27 companies provided an ambiguous answer to the question "what is your business activity" - the answer "hard to say" suggests that the owner or co-owner did not participate in the study). Telephone interviews were conducted in the fourth quarter of 2017.

Out of the surveyed respondents, for 252 it was the first business activity, 121 had previous experience in business, however, the limited research framework did not allow to specify whether they were a portfolio or serial entrepreneurs. The characteristics of the research sample in the groups according to the entrepreneurial experience are presented in Table 1. Chi-square test of independence was applied to assess the relationships between variables and Cramer's $V$ statistics was used as a measure of the effect size.

Table 1

Characteristics of the Research Sample Regarding the Entrepreneurial Experience

\begin{tabular}{|c|c|c|c|c|c|}
\hline Variables & $\begin{array}{l}\text { First business } \\
n=252\end{array}$ & $\begin{array}{l}\text { Subsequent } \\
\text { business } \\
n=121\end{array}$ & $\begin{array}{l}\chi^{2} \\
\text { (df) }\end{array}$ & $\begin{array}{c}\mathrm{p}- \\
\text { value }\end{array}$ & $\begin{array}{c}\text { Cramer's } \\
\text { V }\end{array}$ \\
\hline $\begin{array}{l}\text { Family } \\
\text { business } \\
\text { Yes } \\
\text { No }\end{array}$ & $\begin{array}{l}(n=148) 58.73 \% \\
(n=104) 41.27 \%\end{array}$ & $\begin{array}{l}(n=64) 52.89 \% \\
(n=57) 47.11 \%\end{array}$ & $\begin{array}{l}1.14 \\
(\mathrm{df}=1)\end{array}$ & 0.2866 & 0.0552 \\
\hline $\begin{array}{l}\text { Gender of the } \\
\text { general } \\
\text { manager } \\
\text { Male } \\
\text { Female }\end{array}$ & $\begin{array}{ll}(n=212) & 84.13 \% \\
(n=40) & 15.87 \%\end{array}$ & 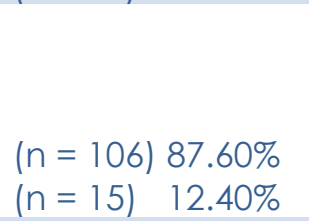 & $\begin{array}{l}0.79 \\
(\mathrm{df}=1)\end{array}$ & 0.3754 & 0.0459 \\
\hline $\begin{array}{l}\text { Sector } \\
\text { Manufacturing } \\
\text { Commerce } \\
\text { Services }\end{array}$ & $\begin{array}{l}(n=105) 41.67 \% \\
(n=33) \quad 13.10 \% \\
(n=114) 45.23 \%\end{array}$ & $\begin{array}{ll}(n=40) & 33.06 \% \\
(n=23) & 19.01 \% \\
(n=58) & 47.93 \%\end{array}$ & $\begin{array}{l}3.59 \\
(\mathrm{df}=2)\end{array}$ & 0.1660 & 0.0981 \\
\hline
\end{tabular}

Source: Authors' work based on the research results

\section{Results}

In the sample, $34,92 \%$ of novice and $45,45 \%$ of habitual entrepreneurs cooperated or cooperates with business environment institutions (Regional Development Agencies, Technology Parks, Business Incubators, Advisory and Training Centres), which can provide various types of services to entrepreneurs (information, training, consulting, financial, etc.). 39,29\% novice (99 entrepreneurs) and 46,28\% (56 entrepreneurs) habitual entrepreneurs received public financial support (subsidy for the implementation of investments; employees participated in training and consultancy 
financed from public funds; other forms where the entrepreneur has received external support).

The most frequently chosen type of public financial support in both groups of entrepreneurs were non-repayable funds (respectively $71,71 \%$ and $69,64 \%$ ). Training support was the second most frequently chosen type of assistance: $36.36 \%$ of novice and $41,07 \%$ of habitual entrepreneurs. The use of all types of support by entrepreneurs is presented in Table 2.

Table 2

The Use of External Public Support by Novice and Habitual Entrepreneurs

\begin{tabular}{|c|c|c|}
\hline Variables & $\begin{array}{l}\text { First business } \\
\qquad n=99\end{array}$ & $\begin{array}{l}\text { Subsequent } \\
\text { business } \\
\mathrm{n}=56\end{array}$ \\
\hline 1. Non-returnable financial support & $71,71 \%$ & $69,64 \%$ \\
\hline 2. Repayable (debt) financial support & $15.15 \%$ & $23,21 \%$ \\
\hline $\begin{array}{l}\text { 3. Advisory support (support in the development of the } \\
\text { project, obtaining a loan.) }\end{array}$ & $12,12 \%$ & $17,86 \%$ \\
\hline $\begin{array}{l}\text { 4. Technological support (support in the } \\
\text { implementation of new technological solutions.) }\end{array}$ & $8,08 \%$ & $5,36 \%$ \\
\hline $\begin{array}{l}\text { 5. Organizational support (management, contacts } \\
\text { with the environment) (the company received support } \\
\text { in introducing organizational changes) }\end{array}$ & $4,04 \%$ & $3,57 \%$ \\
\hline 6. Legal support (exemptions, tax benefits) & $3,03 \%$ & $5,36 \%$ \\
\hline 7. Training support (the company trained employees.) & $36,36 \%$ & $41,07 \%$ \\
\hline
\end{tabular}

Source: Authors' work based on the research results

The most important difficulties related to obtaining external financing from public funds in both groups of entrepreneurs were too complicated procedures for obtaining co-financing $(48,41 \%$ novice and $47,11 \%$ habitual entrepreneurs). The second most important obstacle among novice entrepreneurs was the long time needed to carry out the formalities related to obtaining funding and uncertainty of receiving cofinancing (both $7,14 \%$ ). For habitual entrepreneurs, the next major difficulties were: long time needed to complete formalities related to obtaining funding $(8,26 \%)$, a long time of handling of the submitted application for co-financing $(6,61 \%)$ and low flexibility of spending the received co-financing (6,61\%). $23.02 \%$ novice and $19.01 \%$ habitual entrepreneurs did not indicate any difficulties related to obtaining public funds. Both groups of entrepreneurs use technological, organizational and legal support to a small extent. It should be considered whether this is due to poor matching of the offer with the needs of entrepreneurs, or rather they do not expect such forms of assistance or use them in commercial forms. 
Table 3

The Most Important Difficulties Related to Obtaining External Financing from Public Funds Indicated by Novice and Habitual Entrepreneurs

\begin{tabular}{|c|c|c|}
\hline Variables & $\begin{array}{l}\text { First business } \\
n=252\end{array}$ & $\begin{array}{c}\text { Subsequent } \\
\text { business } \\
n=121\end{array}$ \\
\hline $\begin{array}{l}\text { 1. Too complicated procedures for obtaining co- } \\
\text { financing }\end{array}$ & $48,41 \%$ & $47,11 \%$ \\
\hline $\begin{array}{l}\text { 2. The long time needed to carry out the formalities } \\
\text { related to obtaining funding }\end{array}$ & $7,14 \%$ & $8,26 \%$ \\
\hline $\begin{array}{l}\text { 3. Long time of handling of the submitted application } \\
\text { for co-financing }\end{array}$ & $1,98 \%$ & $6,61 \%$ \\
\hline 4. Uncertainty of receiving co-financing & $7,14 \%$ & $4,13 \%$ \\
\hline $\begin{array}{l}\text { 5. Low flexibility of spending the received co- } \\
\text { financing }\end{array}$ & $3,97 \%$ & $6,61 \%$ \\
\hline $\begin{array}{l}\text { 6. The need to adapt to the strict rules of accounting } \\
\text { and reporting related to the co-financing received }\end{array}$ & $0,79 \%$ & $1,65 \%$ \\
\hline $\begin{array}{l}\text { 7. A lot of paperwork and the need for full settlement } \\
\text { of grants received }\end{array}$ & $5,56 \%$ & $1,65 \%$ \\
\hline $\begin{array}{l}\text { 8. Focusing on the implementation of the project, and } \\
\text { not on the current functioning of the company }\end{array}$ & $1,98 \%$ & $4,96 \%$ \\
\hline 9. There were no difficulties & $23,02 \%$ & $19,01 \%$ \\
\hline
\end{tabular}

Source: Authors' work based on the research results

\section{Discussion}

The article presents the results of the preliminary exploration of the impact of previous experience in business or its lack of entrepreneurial behaviour. The results of the study indicate that habitual entrepreneurs in a greater degree cooperate with business environment institutions and also more often use public funding than novice entrepreneurs. The influence of experience in identifying and using entrepreneurial opportunities as well as developing of an entrepreneurial mindset, demonstrated in the studies of many authors, may have an impact on the search by habitual entrepreneurs for business development opportunities through cooperation with various institutions. Such results may also indicate the use of effectuation by habitual entrepreneurs in order to obtain external business support.

Both groups of entrepreneurs prefer non-returnable financial support as a source of business development. Experienced entrepreneurs also benefit from repayable assistance, more often than novice entrepreneurs. This may be due to the requirements set by support institutions, where a longer period of activity on the market or the achievement of adequate financial results is preferred, as well as the need to provide own contribution. Training support, the second most frequently chosen type of assistance, is used due to less complicated procedures and quick noticeable effects of these activities.

The strongest barrier to the use of external financial support is too complicated procedures for obtaining co-financing. Entrepreneurs often need to involve additional financial and human resources to meet the requirements set by support institutions. Policy makers should consider how to reduce this barrier, especially it is indicated both by novice and habitual (with more knowledge and resources) entrepreneurs. 


\section{Conclusion}

It should be noted that the study has some limitations. The research sample consists of small enterprises, i.e. employing from 10 to 49 people. The inclusion of microenterprises in the study, which constitute the vast majority of companies operating in Poland, would provide a comprehensive picture of entrepreneurial behaviours of habitual entrepreneurs. Another limitation is related to the specificity of the analysed sample associated with innovation. As a result, the study was conducted among innovative companies in which the motives of entrepreneurs, their ability to recognise and exploit opportunities as well as activities undertaken may significantly differ from entrepreneurs not introducing innovations. Due to the fact that, as noted earlier, the study of habitual entrepreneurs was only part of a larger, comprehensive study, the analysis was limited to the comparison of novice and habitual entrepreneurs. Differences between portfolio and serial entrepreneurs were not considered. Another issue to be considered in the deliberations is the impact of previous business experience on the entrepreneurial process, especially the differences in entrepreneurial behaviour of people who failed and succeeded in business. Policy makers need to consider the assets and liabilities associated with prior business experience and with novice entrepreneurs. For example, repeated exit of serial entrepreneurs may be a signal of insufficient managerial skill or resources to grow business. Novice entrepreneurs have often more limited human capital, finance and information resource pools than habitual entrepreneurs. To develop more appropriate policies in-depth research needs to be conducted surrounding the behaviour and entrepreneurial process of novice, portfolio and serial entrepreneurs.

\section{References}

1. Becker, G. S. (1975), Human Capital, NBER, New York, NY.

2. Bridge, S., O'Neill, K., Cromie, S. (2003), Understanding Enterprise, Entrepreneurship and Small Business, Macmillan Press Ltd., Basingstoke.

3. Cieślik, J., (2014), Przedsiębiorczość, polityka, rozwój (Entrepreneurship, policy, development), WA SEDNO, Warszawa.

4. DeTienne, D. R. (2010), "Entrepreneurial exit as a critical component of the entrepreneurial process: Theoretical development", Journal of Business Venturing, Vol. 25, No. 2, pp. 203-215.

5. Dominiak, P. (2005), Sektor MSP we współczesnej gospodarce (The SME sector in the modern economy), PWN, Warszawa.

6. Dominiak, J. (2016), "Rola otoczenia biznesu we wspieraniu przedsiębiorczości i innowacyjności gospodarki. Przykład Wielkopolski" (The Role of Business Environment in Promoting Entrepreneurship and Innovation. An Example of Wielkopolska), Przedsiębiorczość - Edukacja, Vol.12, pp. 98-113.

7. Flynn, D. M. (1993), "A critical exploration of sponsorship, infrastructure, and new organizations", Small Business Economics, Vol. 5, No. 2, pp. 129-156.

8. Lisowska, R. (2014), "Wsparcie rozwoju małych i średnich przedsiębiorstw przez instytucje otoczenia biznesu na przykładzie usługodawców logistycznych w województwie łódzkim" (Support for the development of small and medium enterprises by business environment institutions on the example of logistic service providers in the Lodz region), Ekonomia i Zarzadzanie, Vol. 6, No. 2, pp. 11-22.

9. MacMillan, I. (1986), "To really learn about entrepreneurship, let's study habitual entrepreneurs", Journal of Business Venturing, Vol. 1, No. 3, pp. 241-243.

10. Markiewicz, J. (2010), "Koncepcja funkcjonowania instytucji otoczenia biznesu w aspekcie wspierania innowacyjności sektora MSP w województwie zachodniopomorskim" (The concept of functioning of business environment institutions 
in the aspect of supporting innovation in the SME sector in the West Pomeranian Voivodeship), Ekonomiczne Problemy Usług, No. 48, pp. 33-44.

11. OECD - Organization for Economic Cooperation and Development (1998), Fostering Entrepreneurship, OECD, Paris.

12. Pasanen, M. (2003), "Multiple entrepreneurship among successful SMEs in peripheral locations", Journal of Small Business and Entrepreneurship Development, Vol. 10, No. 4, pp. 418-425.

13. Reynolds, P., Storey, D. J., Westhead, P. (1994), "Cross-national comparisons of the variation in new firm formation rates", Regional Studies, Vol. 28, No. 4, pp. 443-456.

14. Ropęga, J. (2013), Ścieżki niepowodzeń gospodarczych. Redukcja zagrożenia niepowodzeniem jako element strategii małej firmy, Wydawnictwo Uniwersytetu Łódzkiego, Łódź (Paths of business failure. Reduction of failure risk as part of a small business strategy), Wydawnictwo Uniwersytetu Łódzkiego.

15. Sarasvathy, S. D., Menon, A. R., Kuechle, G. (2013), "Failing firms and successful entrepreneurs: serial entrepreneurship as a temporal portfolio", Small Business Economics, Vol. 40, No. 2, pp. 417-434.

16. Shane, S., Khurana, R. (2003), "Bringing individuals back in: the effects of career experience on new firm founding", Industrial and Corporate Change, Vol. 12, No. 3 , pp. 519-544.

17. Storey, D. J. (1994), Understanding the Small Business Sector, Routledge, London.

18. Taylor, M. (1999), "The small firm as a temporary coalition", Entrepreneurship Regional Development, Vol. 11, No. 1, pp. 1-19.

19. Ucbasaran, D., Alsos, G., Westhead, P., Wright, M. (2008), Habitual entrepreneurs, Edward Elgar, Cheltenham.

20. Ucbasaran, D., Westhead, P., Wright, M. (2006), Habitual Entrepreneurs, Aldershot, Edward Elgar, UK.

21. Ucbasaran, D., Wright, M., Westhead, P. (2003), "A longitudinal study of habitual entrepreneurs: Starters and acquirers", Entrepreneurship Regional Development, Vol. 15, No. 3, pp. 207-228.

22. Unger, J. M., Rauch, A., Frese, M., Rosenbusch, N. (2011), "Human capital and entrepreneurial success: a meta-analytical review", Journal of Business Venturing, Vol. 26, No. 3, pp. 341-358.

23. Wennekers, S., Thurik, R. (1999), "Linking entrepreneurship and economic growth", Small Business Economics, Vol. 13, No. 1, pp. 27-55.

24. Westhead, P., Ucbasaran, D., Wright, M. (2003), "Differences between private firms owned by novice, serial and portfolio entrepreneurs: Implications for policy-makers and practitioners", Regional Studies, Vol. 37, No. 2, pp. 187-200.

25. Westhead, P., Ucbasaran, D., Wright, M. (2005), "Decisions, actions and performance: Do novice, serial and portfolio entrepreneurs differ?", Journal of Small Business Management, Vol. 43, No. 4, pp. 393-417.

26. Westhead, P., Ucbasaran, D., Wright, M., Binks, M. (2004), "Policy Toward Novice, Serial and Portfolio Entrepreneurs", Environment and Planning C: Government and Policy, Vol. 22, No. 6, pp. 779-798.

27. Westhead, P., Wright, M. (1998), "Novice, portfolio, and serial founders: are they different?", Journal of Business Venturing, Vol. 13, No. 3, pp. 173-204.

28. Westhead, P., Wright, M. (2015), "The habitual entrepreneur phenomenon", International Small Business Journal, Virtual special issue, pp. 1-16, available at: http://dro.dur.ac.uk/14787/1/14787.pdf?.DDD2+rcvj28+dul4eg (14 May 2017).

29. Westhead, P., Wright, M. (2017), The Habitual Entrepreneur, Routledge, New York, USA.

30. Wiklund, J., Shepherd, D. (2008), "Portfolio entrepreneurship, habitual and novice founders, new entry and mode of organizing", Entrepreneurship Theory and Practise, Vol. 32, No. 4, pp. 701-725. 


\section{About the author}

Jaroslaw Ropega works as the Associate Professor at the University of Lodz, Faculty of Management. His research interests are in the field of entrepreneurship, corporate governance processes of SMEs, business funding, innovation, tackling the economic failures of the SME sector and support system for SME's. In the years 2015 - 2019 he participated in national and international research projects, including as a scientific manager in international projects, e.g.: SGAG - Cooperation for Innovation and the Exchange of Good Practices Strategic Partnerships, DIST - Digital Storytelling for Spreading and Promoting Entrepreneurship. He also has many years' experience as a head and participant of research national projects, e.g.: Failure process in small business. Symptoms and early warning strategy, Failure symptoms of small business. The author can be contacted at email jaroslaw.ropega@uni.lodz.pl. 